\title{
Influence of Fly Ash and Growth Regulator with Soil for Determination of Chlorophyll in Arachis hypogaea L.
}

\author{
Shweta Sao ${ }^{1}$, Pankaj K. Sahu ${ }^{2}$ \\ ${ }^{1}$ Department of Microbiology, Dr. C. V. Raman University Kota, Bilaspur, India; ${ }^{2}$ Department of Botany, Dr. C. V. Raman Univer- \\ sity Kota, Bilaspur, India. \\ Email: sahu.pankaj1@gmail.com
}

Received January $10^{\text {th }}, 2013$; revised August $10^{\text {th }}, 2013$; accepted August $23^{\text {rd }}, 2013$

Copyright (C) 2013 Shweta Sao, Pankaj Kumar Sahu. This is an open access article distributed under the Creative Commons Attribution License, which permits unrestricted use, distribution, and reproduction in any medium, provided the original work is properly cited.

\begin{abstract}
The present investigation was conducted to find out the effect of varying levels of fly ash and growth hormones on the determination of chlorophylls. The experiments were conducted in pots during 2009-2010 with Arachis hypogaea L. (groundnut) grown with different levels of fly ash concentration, and soil was used (various combinations) at Guru ghasidas University, Bilaspur (CG.) India. In fresh leaf, chlorophylls content varies in the plain soil from 0.29 to $0.64 \mathrm{mg}$ $\mathrm{g}^{-1}$, which is less for photosynthetic activities. Arachis hypogaea L. showed maximum germination percentage, increasing leaf area, enhancement of root \& shoot length, whereas Fly ash, bio fertilizers with growth hormone showed minimum values in all parameters. Results showed that, for combination of $\mathrm{A}$ to $\mathrm{E}$, the value of chlorophyll ranged from $0.270 \mathrm{mg} \mathrm{g}^{-1}$ to $0.395 \mathrm{mg} \mathrm{g}^{-1}$, and chlorophyll $\mathrm{b}$ ranged from $0.400 \mathrm{mg} \mathrm{g}^{-1}$ to $0.489 \mathrm{mg} \mathrm{g}^{-1}$, whereas fro total chlorophyll ranged from 0.67 to $0.85 \mathrm{mg} \mathrm{g}^{-1}$. In the present work, chlorophyll a, chlorophyll $\mathrm{b} \&$ total chlorophyll content in fresh leaf, after 45 days, were recorded as $0.395 \mathrm{mg} \mathrm{g}^{-1}, 0.489 \mathrm{mg} \mathrm{g}^{-1}$ and $0.851 \mathrm{mg} \mathrm{g}^{-1}$ while in 90 days were recorded as $10.38 \mathrm{mg} \mathrm{g}^{-1}, 0.48 \mathrm{mg} \mathrm{g}^{-1}$ and $0.86 \mathrm{mg} \mathrm{g}^{-1}$ respectively, in less amount combination of fly ash, soil content with application of growth hormone.
\end{abstract}

Keywords: Arachis hypogaea; Growth Hormone; Soil; Chlorophyll; Fly Ash

\section{Introduction}

Arachis hypogaea L. (Groundnut) is a small branched herb, erects or trails on the ground and bears small yellow flowers. The cylindrical reticulated two seeds pod within the outer shell. Increased concentration of cement dust pollutants causes invisible injuries like progressive decline in the physiological process such as photosynthetic ability and respiration rate of leaves. Arachis hypogaea $\mathrm{L}$. can adapt to a variety of soil and climatic conditions and the use of fly ash as a liming agent in mono and dicotyledonous plants for better crop yields. Fly ash has tremendous potential as a nutrient supplement and plays a favourable role in increasing growth and yield of ground nut [1-5]. Fly ash has similar physicochemical properties with soil. It can mix homogeneously and can improve agronomic properties of soil [6]. Fly ash is the treasure of trace elements. It makes the trace element readily available to the crop when mixed with soil [7,8]. Auxin increased respiration rates are suggestive of parallel relationship of growth, respiratory activity and found to in- crease RNA synthesis in tissue of higher plants [9]. Use of fly ash ameliorates soil acidity for maximum uptake of trace elements from fly ash which acted as a reserve of trace element when mixed in soil. Fly ash helps to retain water in the soil and also helped $\mathrm{CO}_{2}$ evolution. The plant hormone Indole acetic acid and Gibberellic acid helped protein, oil synthesis and also increased respiration rate. Soil metabolic activities, activities of amylase invertase and protease, chlorophyll a $\&$ b, carotenoid and protein content are increased in fly ash amended soil [1014].

Cement dust pollutants blocked the stomata, reduction in number of annual crops and due to cement dust decreased the productivity and concentration of chlorophyll in a number of crops reported $[15,16]$. The reduction in protein, starch, yield and phytomass of groundnut occurred due to cement dust Arachis hypogaea L. [17]. Protein synthesis decreased due to the low chlorophyll and reduced leaf area surface similar findings were reported [18]. Remunerative responses of groundnut crop to fer- 
tilizer application have been observed both under irrigated and rain fed conditions in India [19]. Increase in groundnut yield due to the application of NPK was also reported [20].

\section{Material and Methods}

Determination of chlorophyll a, b and total chlorophyll [21], Chlorophyll is extracted in $90 \%$ acetone from $1 \mathrm{gm}$ leaves of Arachis (systronics-20). Using the absorption coefficient, the amount of chlorophyll a, b and total chlorophyll were estimated in the leaves of Arachis hypogaea L. $1 \mathrm{gm}$ of well mixed representative sample of leaves were finely cut and ground with $20 \mathrm{ml}$ of $80 \%$ acetone, centrifuged (5000 rpm 5 minutes) and supernatant liquid was transferred to a $100 \mathrm{ml}$ volumetric flask. The procedure was repeated till residue become colourless. Volume was made up to $100 \mathrm{ml}$ mark with $80 \%$ acetone in all the three cases individually.

The amount of Chlorophyll was calculated using the formula mentioned below:

$\mathrm{Mg}$ chlorophyll a/gram of leave

$=12.7(\mathrm{~A} 615) \times \mathrm{V} / 1000 \times \mathrm{W}$

Mg chlorophyll a/gram of leave

$=12.7(\mathrm{~A} 615) \times \mathrm{V} / 1000 \times \mathrm{W}$

$\mathrm{Mg}$ total chlorophyll /gram of leave s

$=20.2(\mathrm{~A} 645)-8.02(\mathrm{~A} \times 663) \times \mathrm{V} / 1000 \times \mathrm{W}$

where, $\mathrm{A}=$ Absorbance at specific wave lengths, $\mathrm{V}=$ Final volume of chlorophyll extract in $80 \%$ acetone, $\mathrm{W}=$ Fresh weight of leaves extracted.

Chlorophyll a and b, Carotenoids were extracted from the leaves and estimated by the method of Arnon (1949). Absorbance was measured at 645, 663 and $480 \mathrm{~nm}$ with a spectrophotometer (U200 1Hitachi) against 80 per cent acetone as blank. Chlorophyll content was calculated using the formula proposed by Arnon (Table 1).

\section{Result and Discussion}

In the present work chlorophyll a, chlorophyll $\mathrm{b}$ and total chlorophyll in fresh leaf were observed as $0.35,0.29$ and $0.64 \mathrm{mg} \mathrm{g}^{-1}$ respectively while after 45 days chlorophylls were estimated as $0.395 \mathrm{mg} \mathrm{g}^{-1}, 0.489 \mathrm{mg} \mathrm{g}^{-1}$ and 0.851 $\mathrm{mg} \mathrm{g}^{-1}$. The value of chlorophyll a was observed as 0.270 $\mathrm{mg} \mathrm{g}^{-1}, 0.280 \mathrm{mg} \mathrm{g}^{-1}, 0.300 \mathrm{mg} \mathrm{g}^{-1}, 0.377 \mathrm{mg} \mathrm{g}^{-1}$ and $0.395 \mathrm{mg} \mathrm{g}^{-1}$ in the set A, B, C, D and E respectively, whereas for chlorophyll $\mathrm{b}$ the value was recorded as $0.400 \mathrm{mg} \mathrm{g}^{-1}, 0.454 \mathrm{mg} \mathrm{g}^{-1}, 0.460 \mathrm{mg} \mathrm{g}^{-1}, 0.480 \mathrm{mg} \mathrm{g}^{-1}$ and $0.489 \mathrm{mg} \mathrm{g}^{-1}$ respectively. For total chlorophyll it was $0.670 \mathrm{mg} \mathrm{g}^{-1}, 0.734 \mathrm{mg} \mathrm{g}^{-1}, 0.760 \mathrm{mg} \mathrm{g}^{-1}, 0.848 \mathrm{mg}$ $\mathrm{g}^{-1}$ and $0.851 \mathrm{mg} \mathrm{g}^{-1}$ respectively (Figure 1).

In plain soil, chlorophyll $\mathrm{a}$, chlorophyll $\mathrm{b}$ and total chlorophyll were present as $0.35,0.29$ and $0.64 \mathrm{mg} \mathrm{g}^{-1}$ in fresh leaf, respectively, which is less for photosynthetic activities. In the present work chlorophylls were present in $10.38 \mathrm{mg} \mathrm{g}^{-1}, 0.48 \mathrm{mg} \mathrm{g}^{-1}$ and $0.86 \mathrm{mg} \mathrm{g}^{-1}$ fresh leaf after 90 days. For $\mathrm{A}$ to $\mathrm{E}$ treatment chlorophyll values were $0.270 \mathrm{mg} \mathrm{g}^{-1}, 0.280 \mathrm{mg} \mathrm{g}^{-1}, 0.300 \mathrm{mg} \mathrm{g}^{-1}$ and 0.377 $\mathrm{mg} \mathrm{g}^{-1}$ fresh leaf, respectively. For chlorophyll $\mathrm{b}$, values were $0.400 \mathrm{mg} \mathrm{g}^{-1}$ fresh leaf, $0.454 \mathrm{mg} \mathrm{g}^{-1}$ fresh leaf, $0.460 \mathrm{mg} \mathrm{g}^{-1}$ fresh leaf and $0.480 \mathrm{mg} \mathrm{g}^{-1}$ fresh leaf, respectively and total chlorophyll in combination A was found to be $0.67 \mathrm{mg} \mathrm{g}^{-1}$ fresh leaf and $\mathrm{B}-0.73 \mathrm{mg} / \mathrm{gm}$ fresh leaf and $\mathrm{C}-0.76 \mathrm{mg} \mathrm{g}^{-1}$ fresh leaf, and in combination D, $0.85 \mathrm{mg} \mathrm{g}^{-1}$ fresh leaf (fig). Treatments with ABA and $\mathrm{GA}_{3}$ significantly increased the total chlorophyll contents in Mentha plants. Similar results were observed that in Paclo butrazol treated barley and carrot and Paclobutrazol treated leaves were dark green due to high chlorophyll content in potato [22-24]. In combination of 30\% FA $+70 \%$ Soil + GH, Arachis hypogaea L. showed maximum germination \%, Increasing leaf area, and enhancement of shoot length, whereas Fly ash + NPK + GH showed minimum all parameters.

Gibberellic acid increased the vegetative growth and pigment concentration in maize [25]. Foliar application of $\mathrm{GA}_{3}$ improved the chlorophyll levels in salinity stressed maize plants [26]. These results suggested that plain soil could not contribute to chlorophyll formation. It was performed that the addition of NPK had increased chlorophyll formation by producing nitrogen and nutrient management for sustainable groundnut productivity in India [27-30]. Mg has contributed its best role in structural constitution of chlorophyll a and $b$, and its absence causes early derangement of chloroplast structure [31], while $\mathrm{Fe}$ is contributing its important role to chlorophyll synthesis [32]. Nutrient management for the sustainable productivity in India was performed that fly ash and growth hormone increased the oil content in linseed crop $[33,34]$. IAA and GA hormones increase the germination percentage [35] while the use of IAA and GA hormone regulates the biochemical process of the plant, which results higher percentage of oleic and oleic acid content [36]. IAA and GA increase the stem and root elongation and the plant growth parameters like root length, shoot length, number of leaves, leaf area increase, and seed contents also increase. Increasing number of leaves and leaf area increases the level of the chlorophyll a \& b [37]. Growth biochemical and yield responses of groundnut are due to the effect of cement dust deposition [17].

\subsection{Effect of Plant Growth Regulators on Chlorophyll Content}

The total chlorophyll contents of the leaves increase with the age in control and treated Mentha leaves. The maximum increase was found on 90 DAP in DIZ treatments and it was 132.91 percent over control. Among the treat- 
Table 1. Effect of various combinations with fly ash in leaves formation, root \& shoot growth.

\begin{tabular}{|c|c|c|c|c|c|c|}
\hline \multirow{2}{*}{ S.N. } & \multirow{2}{*}{ Combinations } & \multirow{2}{*}{ Pot number } & \multirow{2}{*}{$\%$ Germination } & \multirow{2}{*}{$\frac{\text { Number of Leaves }}{\text { In } 45 \text { days }}$} & \multirow{2}{*}{$\frac{\text { Leaf area }\left(\mathrm{cm}^{2}\right)}{\text { In } 45 \text { days }}$} & \multirow{2}{*}{$\begin{array}{c}\text { Shoot length }(\mathrm{cm}) \\
\text { After } 45 \text { days }\end{array}$} \\
\hline & & & & & & \\
\hline 1. & Fly ash $100 \%$ & $1,2,3$ & ------ & ----- & ----- & ------ \\
\hline 2. & Plain soil $100 \%$ & $4,5,6$ & 42 & 243 & 2604.71 & 48.03 \\
\hline 3. & $10 \% \mathrm{FA}+90 \%$ Soil & $7,8,9$ & 42 & 251 & 2511.16 & 48.12 \\
\hline 4. & $20 \% \mathrm{FA}+80 \%$ Soil & $10,11,12$ & 41 & 229 & 2641.70 & 49.01 \\
\hline 5. & $30 \% \mathrm{FA}+70 \%$ Soil & $13,14,15$ & 56 & 235 & 2711.12 & 48.17 \\
\hline 6. & $40 \% \mathrm{FA}+60 \%$ Soil & $16,17,18$ & 54 & 221 & 2511.18 & 45.13 \\
\hline 7. & $50 \% \mathrm{FA}+50 \%$ Soil & $19,20,21$ & 42 & 220 & 2206.31 & 45.11 \\
\hline 8. & $60 \% \mathrm{FA}+40 \%$ Soil & $22,23,24$ & 33 & 207 & 2014.00 & 44.41 \\
\hline 9. & $70 \% \mathrm{FA}+30 \%$ Soil & $25,26,27$ & 35 & 211 & 1842.42 & 42.31 \\
\hline 10. & $80 \% \mathrm{FA}+20 \%$ Soil & $28,29,30$ & 30 & 185 & 1721.21 & 40.21 \\
\hline 11. & $90 \% \mathrm{FA}+10 \%$ Soil & $31,32,33$ & 20 & 164 & 1336.11 & 35.62 \\
\hline 12. & Plan Soil + NPK & $34,35,36$ & 48 & 264 & 3001.89 & 50.53 \\
\hline 13. & $10 \% \mathrm{FA}+90 \%$ Soil + NPK & $37,38,39$ & 66 & 276 & 3520.95 & 52.46 \\
\hline 14 & $20 \% \mathrm{FA}+80 \%$ Soil + NPK & $40,41,42$ & 78 & 306 & 3873.87 & 54.63 \\
\hline 15. & $30 \% \mathrm{FA}+70 \%$ Soil $+\mathrm{NPK}$ & $43,44,45$ & 60 & 265 & 3216.08 & 50.00 \\
\hline 16. & $40 \% \mathrm{FA}+60 \%$ Soil $+\mathrm{NPK}$ & $46,47,48$ & 68 & 246 & 3018.00 & 48.17 \\
\hline 17. & $50 \% \mathrm{FA}+50 \%$ Soil $+\mathrm{NPK}$ & $49,50.51$ & 42 & 241 & 2752.11 & 44.22 \\
\hline 18. & $60 \% \mathrm{FA}+40 \%$ Soil $+\mathrm{NPK}$ & $52,53,54$ & 35 & 217 & 2321.19 & 45.02 \\
\hline 19. & $70 \% \mathrm{FA}+30 \%$ Soil + NPK & $55,56,57$ & 24 & 171 & 2003.93 & 42.51 \\
\hline 20. & $80 \% \mathrm{FA}+20 \%$ Soil + NPK & $58,59,60$ & 20 & 125 & 1162.75 & 42.13 \\
\hline 21. & $90 \% \mathrm{FA}+10 \%$ Soil + NPK & $61,62,63$ & 10 & 101 & 1151.52 & 50.22 \\
\hline 22. & $10 \% \mathrm{FA}+90 \%$ Soil $+\mathrm{NPK}$ & $64,65,66$ & 45 & 234 & 3037.76 & 52.63 \\
\hline 23. & $20 \% \mathrm{FA}+80 \%$ Soil + NPK & $67,68,69$ & 78 & 292 & 3881.87 & 53.71 \\
\hline 24. & $30 \% \mathrm{FA}+70 \%$ Soil $+\mathrm{NPK}$ & $70,71,72$ & 99 & 327 & 4478.3 & 57.00 \\
\hline 25. & $40 \% \mathrm{FA}+60 \%$ Soil + NPK & $73,74,75$ & 78 & 271 & 3721.88 & 51.21 \\
\hline 26. & $50 \% \mathrm{FA}+50 \%$ Soil $+\mathrm{NPK}$ & $76,77,78$ & 66 & 265 & 3521.33 & 48.27 \\
\hline 27. & $60 \% \mathrm{FA}+40 \%$ Soil $+\mathrm{NPK}$ & $79,80,81$ & 58 & 243 & 3321.07 & 45.22 \\
\hline 28. & $70 \% \mathrm{FA}+30 \%$ Soil + NPK & $82,83,84$ & 40 & 221 & 3516.24 & 43.88 \\
\hline 29. & $80 \% \mathrm{FA}+20 \%$ Soil + NPK & $85,86,87$ & 41 & 207 & 3361.23 & 43.28 \\
\hline 30. & $90 \% \mathrm{FA}+10 \%$ Soil + NPK & $88,89,90$ & 20 & 142 & 2321.21 & 38.33 \\
\hline 31. & $10 \% \mathrm{FA}+90 \%$ Soil $+\mathrm{GH}$ & $91,92,93$ & 50 & 237 & 2711.22 & 50.92 \\
\hline 32. & $20 \% \mathrm{FA}+80 \%$ Soil $+\mathrm{GH}$ & $94,95,96$ & 54 & 262 & 2822.61 & 52.92 \\
\hline 33. & $30 \% \mathrm{FA}+70 \%$ Soil $+\mathrm{GH}$ & $97,98,99$ & 60 & 254 & 3416.88 & 54.13 \\
\hline 34. & $40 \% \mathrm{FA}+60 \%$ Soil $+\mathrm{GH}$ & $100-102$ & 58 & 242 & 3092.12 & 52.92 \\
\hline 35. & $50 \% \mathrm{FA}+50 \%$ Soil $+\mathrm{GH}$ & $103-105$ & 52 & 251 & 2761.73 & 51.52 \\
\hline 36. & $60 \% \mathrm{FA}+40 \%$ Soil $+\mathrm{GH}$ & 106-108 & 41 & 223 & 2516.22 & 48.12 \\
\hline 37. & $70 \% \mathrm{FA}+30 \%$ Soil $+\mathrm{GH}$ & $109-111$ & 36 & 185 & 2014.83 & 45.31 \\
\hline 38. & $80 \% \mathrm{FA}+20 \%$ Soil $+\mathrm{GH}$ & $112-114$ & 32 & 161 & 1989.36 & 45.77 \\
\hline 39. & $90 \% \mathrm{FA}+10 \%$ Soil $+\mathrm{GH}$ & $115-117$ & 20 & 119 & 1681.14 & 42.83 \\
\hline 40. & Fly ash + NPK + GH & $118-120$ & 20 & 72 & 998.31 & 35.45 \\
\hline
\end{tabular}




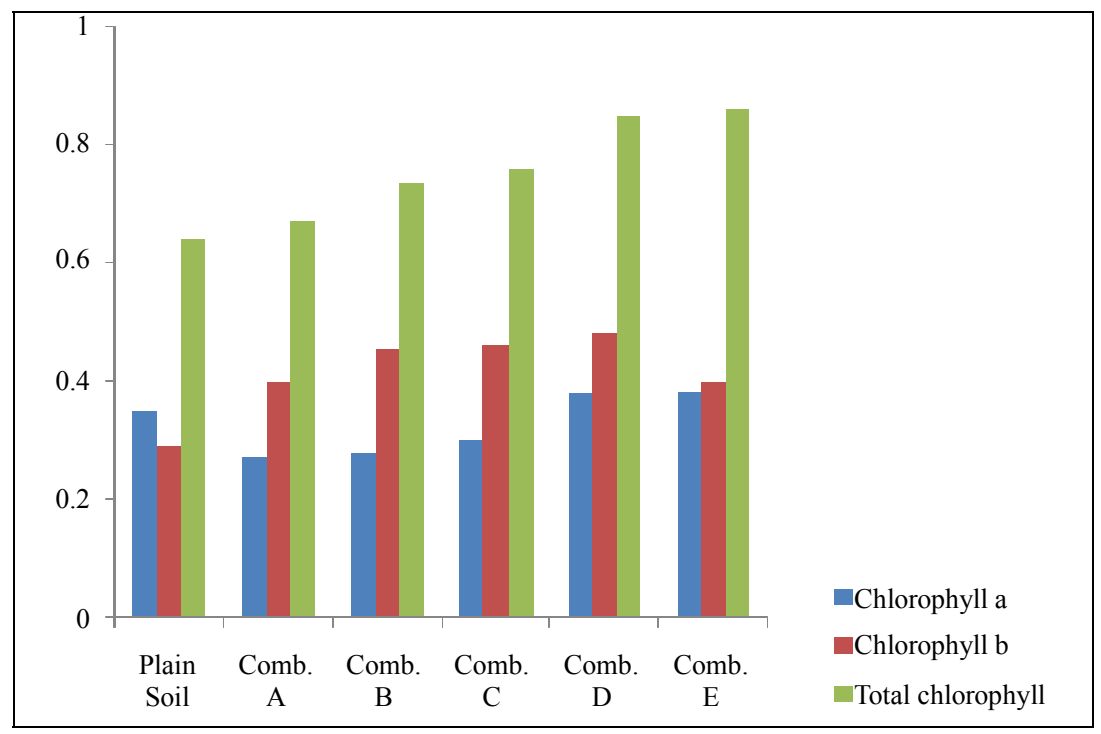

Figure 1. Showing effect of various concentrations for chlorophylls determination.

ments $\mathrm{ABA}$ and GA3 slightly increased and they were 123.00 and 122.11 respectively on 90 DAP.

\subsection{Effect of Plant Growth Regulators on Plant Height}

The total height of the plant increased with the age in the control, $\mathrm{ABA}$ and $\mathrm{GA}_{3}$ treated Mentha plants, but it decreased under DIZ treatments. The increase was higher in gibberellic acid treated compared to ABA. Highest plant height was noted in 90 DAP under GA3 treatments and it was nearly 136.66 percent over control. The gibberellic acid treated plants increased the plant height. Triazole treatments reduced stem elongation and plant height in Plectranthus forskholii, Manihot esculenta and Catharanthus roseus [38-40]. $\mathrm{GA}_{3}$ exerts profound effects on fundamental process of plant growth and development. $\mathrm{GA}_{3}$ is widely regarded as a growth promoting compound that positively regulates processes such as seed germination, stem elongation and leaf expansion [41]. Split application of potassium equally at sowing and at 35 DAS increased the pod yield of groundnut, and higher availability of plant nutrients consequently had higher growth parameters in the fertilized treatments and higher yield of groundnut $[42,43]$. The application of 25:50:00, NPK kg ha ${ }^{-1}$ giving the highest plant height and total dry matter per plant at harvest and yield attributes of summer groundnut was reported [44]. Significant increase in pod yield of groundnut was observed at a fertilizer level of 30:60:30 kg NPK ha ${ }^{-1}$, and the increase in yield was 30 percent higher than lower level of fertilizer doses [45]. It was observed that supplemental nitrogen either through soil or foliage at 50 and 70 DAS in addition to recommended dose of NPK increased the yield of groundnut [46]. The effect of trace elements on yield and nutrient uptake was studied in groundnut [47]. The influence of cement dust on growth and yield component of Arachis hypogaea popularly grew in and around the cement factory area in India.

\section{Acknowledgements}

The authors are thankful to Head, Department of Biotechnology, Guru Ghasidas University, Bilaspur (C.G.) India for encouragement and support.

\section{REFERENCES}

[1] F. Ahmad and K. H. Ton, "Effect of Lime and Organic Matter on Soil with AI Toxicity," Soil Science Society of America, Vol. 50, 1986, pp. 605-661. doi:10.2136/sssaj1986.03615995005000030023x

[2] R. W. Millar and R. R. Donahue, " $\mathrm{H}+$ and $\left[\mathrm{Al}(\mathrm{OH})^{2}\right]+$ Toxicity in Soil in 'Soil in Our Environment'," Prentice Hall of India, New Delhi, 1997, pp. 241-251.

[3] V. H. Rai, D. K. Gupta, Akhtar and A. Pal, "Performance of Seed Germination and Growth in Victoria Coal Fly Ash Amended Soil," Journal of Environmental Biology, Vol. 24, No. 1, 2003, pp. 9-15.

[4] P. K. Sarangi and P. G. Mishra, "Soil Metabolic Activities and Yield in Ground Nut in Fly Ash Amended Soil," Research Journal of Chemistry and Environment, Vol. 2, No. 2, 1998, pp. 117-119.

[5] L. P. Singh and A. Siddhiqui, "Effect of Fly Ash on Growth and Yield Three Cultivars of Rice," Bioresource Technology, Vol. 86, No. 1, 2003, pp. 73-78. doi:10.1016/S0960-8524(02)00111-6

[6] A. C. Change, L. J. Lund, A. L. Page and J. E. Warneke, "Physical Properties of Fly Ash Amended Soil," Journal Environment Quality, Vol. 6, No. 3, 1979, pp. 267-270. doi:10.2134/jeq1977.00472425000600030007x

[7] G. B. Dreiher and J. A. Schleicher, "Trace Elements in 
Coal by Optical Emission Spectroscopy," Advances in Chemistry, Vol. 35, 1975, p. 141.

[8] C. O. Plank and D. C. Mortens, "Boron Availability as Influenced by Application of Fly Ash to Soil," Soil Science Society of America Proceeding, Vol. 38, 1974, pp. 974-977.

doi:10.2136/sssaj1974.03615995003800060038x

[9] J. R. Still and W. G. Pill, "Germination, Emergence and Seedlings Growth of Tomato and Impatiens in Response to Seed Treatment with Aclobutrazol," Horticultural Science, Vol. 38, 2003, pp. 1201-1204.

[10] K. Bhandari, "Studies on the Effect of Fly Ash and Plant Hormones Treated Soil in the Increased Protein and Amino Acid Content in the Seeds Ground Nut," Asian Journal of Chemistry, Vol. 20, 2006, p. 15.

[11] M. A. Bozkurt and I. Karacal, "Quantitative Relationship between Nutrient Contents and Oil Quality of Sunflower Seed," Journal of Food \& Science Technology, Vol. 38, No. 6, 2001, pp. 635-638.

[12] Y. R. Chadha, "Lime Requirement for Proper Growth of Ground Nut, Wealth of India," CSIR Publication, New Delhi, 1998, pp. 90-102.

[13] Y. R. Chadha, "Poorly Developed Seed Kernels in Ground Nut Due to Ca Deficiency. Wealth of India," CSIR Publication, New Delhi, 1998, pp. 103-109.

[14] V. Goyel, M. R. Augar and D. K. Shrivastava, "Studies on the Effect of Fly Ash Treated Soil on the Increased Protein on the Effect Increased Protein Content in the Seeds of Glycine max (Soybean)," Asian Journal of Chemistry, Vol. 14, pp. 180-182.

[15] A. M. Farmer, "The Effect of Dust on Vegetation-A Review," Environmental Pollution, Vol. 79, No. 1, 1993, pp. 63-75. doi:10.1016/0269-7491(93)90179-R

[16] R. N. Sato, H. K. Kene, R. V. Nalamwar and R. B. Ulemale, "Effect of Cement Dust Pollution on Growth and Yield of Cotton," Annals of Plant Physiology, Vol. 7, 1993, pp. 73-77.

[17] D. Raajasubramanian, P. Sundaramoorthy, L. Baskaran, K. Sankar Ganesh, A. L. A. Chidambaram and M. JegaNathan, "Cement Dust Pollution on growth and Yield Attributes of Groundnut (Arachis hypogaea L.)," International Multidisciplinary Research Journal, Vol. 1, No.1, 2011, pp. 31-36.

[18] T. Baszynski, M. Warchodowa, Z. Krupa, A. Tukendorf, M. Krol and D. Z. Wolinska, "The Effect of Magnesium Deficiency on Photochemical Activities of Rape and Buckwheat Chloroplasts," Zeitschrift fur Pflanzenphysiologie, Vol. 99, 1980, p. 295.

[19] J. S. Kanwar, H. L. Nijhawan and S. K. Raheja, "Groundnut Nutrition and Fertilizer Responses in India," ICAR, New Delhi, 1983.

[20] V. V. Angadi, S. V. Patil, M. N. Shilvantar and B. M. Chittapur, "Effect of NPK Levels and Split Application of $\mathrm{N}$ on Growth and Yield of bunch Groundnut in Vertisol under Irrigation System," Karnataka Journal of Agriculture Science, Vol. 3, No. 1-2, 1980, pp. 9-14.

[21] S. Sadashivam and Manickchand, "Biochemical Methods: Estimation of Fatty Acids and Oils," New Age Interna- tional Publication Limited, New Delhi, 1996, pp. 102107.

[22] S. Sunitha, M. R. Perras, D. E. Falk, R. Zhang, P. Pharis and R. A. Fletcher, "Relationship between Gibberellins, Height and Stress Tolerance on Barley Seedlings," Plant Growth Regulation, Vol. 42, No. 2, 2004, pp. 125-135. doi:10.1023/B:GROW.0000017492.56792.64

[23] R. Gopi, C. A. Jaleel, R. Sairam, G. M. A. Lakshmanan, M. Gomathinayagam and R. Pannerselvam, "Differential Effects of Hexaconazole and Paclobutrazol on Biomass, Electrolyte Leakage, Lipid per Oxidation and Antioxidant Potential of Daucus carota L.," Colloids and Surfaces B: Biointerfaces, Vol. 60, 2007, p. 180. doi:10.1016/j.colsurfb.2007.06.003

[24] T. Tekalign, S. Hammes and J. Robbertse, "Paclobutrazol Induced Leaf, Stem and Root Anatomical Modifications in Potato," Horticulture Science, Vol. 40, No. 5, 2005, pp. 1343-1346

[25] C. Kaya, A. Levent Tuna, A. Alfredo and C. Alves, "Gibberellic Acid Improves Water Deficit Tolerance in Maize Plants," Acta Physiologiae Plantarum, Vol. 28, No. 4, 2006, pp. 331-337. doi:10.1007/s11738-006-0029-7

[26] A. L. Tuna, K. Cengiz, M. Dikilitas and D. Higgs, "The Combined Effect of Gibberellic Acid and Salinity on Same Antioxidant Enzyme Activities, Plant Growth Parameter and Nutritional Status in Maize Plants," Environmental and Experimental Botany, Vol. 62, 2008, p. 19. doi:10.1016/j.envexpbot.2007.06.007

[27] J. C. Sadhna and B. M. Khan, "Nitrogen Fixation," Journal of Science Industrial Research, Vol. 36, 1977, pp. 495-533.

[28] J. C. Sadhna and B. M. Khan, "Nitrogen Fixation in Ground Nut (Arachis hypogaea)," Journal of Science Industrial Research, Vol. 36, 1977, pp. 515-516.

[29] D. L. Purich and H. J. Fromm, "Studies on Factors Influencing Enzyme Responses," Journal of Biological Chemistry, Vol. 31, 1972, pp. 247-255.

[30] E. J. Hawitt and T. A. Smith, "Plant Mineral Nutrition," English University, London, 1974, pp. 131-133.

[31] J. M. Whatley, "Ultra Structural Changes in Chloroplast of Phaseolus vulgaris," New Phytology, Vol. 70, 1971, pp. 725-742. doi:10.1111/j.1469-8137.1971.tb02573.x

[32] O. T. G. Johns, "Ferro Cheletase of Spinich Chloroplast," Journal of Biochemistry, Vol. 107, No. 1, 1968, pp. 113119.

[33] P. Veeramani and K. Subrahmaniy, "Nutrient Management for Sustainable Groundnut Productivity in India-A Review," International Journal of Engineering Science and Technology, Vol. 3, No. 11, 2011, pp. 41-45.

[34] K. Bhandari,"Effect of Fly Ash on Growth and Yield of Linseed Crop," Ph.D. Thesis, G.G.D. University, Bilaspur, 2004.

[35] K. Rao and S. Gideron, "Use of Plant Hormones on Germination," Indian Journal of Oil Seed, Vol. 1, 1957, p. 247.

[36] A. Bawaria, "Oil Analysis of Sunflower, Mustard Seed, Ground Nut, Grown in Ameliorated Acidic Soil," Ph.D. 
Thesis, G. G. D. University, Bilaspur C.G, 2006.

[37] P. J. Davies, "The Plant Hormones: Their Nature, Occurrence and Function," In: P. J. Davis, Ed., Plant Hormones: Physiology, Biochemistry and Biology, Kluwer Acadamic Publisher, Drodrecht, 1995, pp. 1-12.

[38] G. M. A. Lakshmanan, C. A. Jaleel, M. Gomathinayagam and R. Panneerselvam, "Changes in Antioxidant Potential and Sink Organ Dry Matter with Pigment Accumulation Induced by Hexaconazole in Plectranthus forskholii Briq," Comptes Rendus Biologies, Vol. 330, No. 11, 2007, pp. 814-820. doi:10.1016/j.crvi.2007.08.008

[39] M. Gomathinayagam, C. A. Jaleel, G. M. A. Lakshmanan and R. Panneerselvam, "Change in Carbohydrate Metabolism by Triazole Growth Regulators in Cassava (Manihot esculenta Crantz); Effects on Tuber Production and Quality," Comptes Rendus Biologies, Vol. 330, No. 9, 2007, pp. 644-655. doi:10.1016/j.crvi.2007.06.002

[40] C. A. Jaleel, R. Gopi, P. Manivannan, M. Gomathinayagam, P. V. Murali and R. Panneerselvam, "Soil Applied Propiconazole Alleviates the Impact of Salinity on Catharanthus roseus by Improving Antioxidant Status," Pesticide Biochemistry and Physiology, Vol. 90, No. 2, 2008, pp. 135-139. doi:10.1016/j.pestbp.2007.11.003

[41] S. M. Swain and D. P. Singh, "Tale Tales from Sly Dwarves: Novel Functions of Gibberellins Plant Development," Trends of Plant Science, Vol. 10, No. 3, 2005, pp. 123-129. doi:10.1016/j.tplants.2005.01.007

[42] C. V. Patil, N. A. Yaledahalli and S. S. Prakash, "Integrated Nutrient Management for Sustainable Productivity of Groundnut in India," National Workshop on Groundnut Seed Technology, Raichur, 2003.

[43] S. S. Mondal and S. B. Goswami, "Effect of Split Application of Potassium on Rainfed Groundnut," Journal of Potassium Research, Vol. 7, No. 4, 1991, pp. 304-308.

[44] P. Parasuraman, M. N. Budher, P. Manickasundaram and M. Nandanam, "Response of Sorghum, Finger Millet and Groundnut to the Silt Application and Combined Use of Organic Matter and Inorganic Fertilizer under Rainfed Conditions," Indian Journal of Agronomy, Vol. 43, No. 3, 1998, pp. 528-532.

[45] D. S. Thorave and M. B. Dhonde, "Morphological Indices and Yield Attributes as Influenced by Integrated Nutrient Management in Summer Groundnut," Annals of Plant Physiology, Vol. 21, No. 2, 2007, pp. 186-188.

[46] V. Kumar, B. C. Ghose, B. Ravi and S. Karmakar, "Effect of Irrigation and Fertilizer on Yield, Water-Use Efficiency and Nutrient Uptake of Summer Groundnut," Indian Journal Agronomy, Vol. 45, No. 4, 2000, pp. 756760.

[47] T. Chitdeshwari and S. Poongathai, "Yield of Groundnut and Nutrient Uptake as Influenced by Zn, B, and S," Agricultural Science Digest, Vol. 23, 2003, pp. 263-265. 